\title{
Achievement of Abraham Maslow's Needs Hierarchy Theory among Teachers: Implications for Human Resource Management in The Secondary School System in Rivers State
}

\author{
Adiele E.E. ${ }^{1} \&$ Abraham, Nath. M. ${ }^{2}$ \\ ${ }^{1}$ Ignatius Ajuru University of Education, Port Harcourt, Rivers State, Nigeria \\ ${ }^{2}$ Department of Educational Management, Faculty of Education, University of Port Harcourt, Port Harcourt, Rivers \\ State, Nigeria \\ *Corresponding author: Department of Educational Management, Faculty of Education, University of Port Harcourt, \\ Rivers State, NigeriaＥ-mail: nathabraham@yahoo.com
}

Received: November 24, 2012

Accepted: December 5, 2012 Online Published: May 18, 2013

doi:10.5430/jct.v2n1p140

URL: http://dx.doi.org/10.5430/jct.v2n1p140

\begin{abstract}
The study investigated the achievement of Abraham Maslow's need hierarchy theory among secondary school teachers in Rivers State. A 25-item questionnaire was designed, validated and administered on a sample of 500 teachers drawn from 245 secondary schools in Rivers State. The result revealed that secondary school teachers indicated insignificant level achievement of lower and higher order needs of Abraham Maslow's need theory which reflected in their low level of achievement of hunger, shelter, security, belongingness, friendship and affection needs; as well as poor achievement of self respect, recognition, self actualization and potential self development. The effect of this on teacher motivation is the declining quality of teaching and learning, and unethical practices to 'make ends meet' among teachers. It is recommended that teachers' remunerations be kept at par with those of their counterparts in other professions. Above all, government must muster the will power to upgrade existing facilities and work conditions in the secondary school system; this will engender greater commitment and productivity of teachers.
\end{abstract}

Keywords: achievement; Abraham Maslow; needs hierarchy theory; secondary school system, human resource management, teachers, Rivers State

\section{Background to the Study}

Motivation is defined as the forces, drives, needs, tension states, or other mechanisms that starts and maintain voluntary activity towards the achievement of personal goals' (Hoy \& Miskel, 1987:176). Motivation is geared towards increasing people's efforts and performance. That is why Bateman and Snell (1999:440) see it as a "force that energizes, directs and sustains a person's effort towards the achievement of goals".

Individual motives are usually based on needs, thus, there are needs that give rise to wants which cause tension. These in turn give rise to actions, which result in satisfaction. Motivation therefore is the direct result of needs, desires and expectations which energies behavior. If there is a deficiency in what the individual wants, expects or anticipates, tension is created, the individual then adopts certain behavior that will lead not just to the reduction of tension, but also to the achievement of the expected desires.

The secondary school teacher just like any other worker has his individual motives based on needs, desires and expectations which energies his behavior towards the achievement of goals. The primary task of the school administrator therefore is to ensure that the school teacher functions effectively and efficiently so as to achieve results. To achieve this task, it is the duty of the school manager to be able to know what motivates the teacher. Motivation is a central construct in school administration. The school exists primarily for teaching and learning, and so, anything that will enhance teaching and learning should be of paramount importance to the school manager/administrator (Abraham, 2003). 
Some schools of thought have written about theories of human motivation as a tool for effective administration. Evidence is drawn from the works of Abraham Maslow (1974); Alderfer (1960. 1970), Herzberg, Fritz Heider; Skinner (1960), Adams (1965), and Douglas McGregor (160). These scholars are all in agreement that motivation is a sine-qua-non to organizational goal attainment, and that, the level of organizational effectiveness is largely dependent on the level of motivation of its workforce.

In Rivers State of Nigeria, a lot has been done in terms of educational infrastructural development. But not much is known about the level of preparedness of the workforce in the area of quality delivery of education. The aggressive infrastructural development in education in Rivers State has triggered off concern for investigation into the level of motivation of teachers towards the achievement of quality education in the state. This concern has become more critical for a country that is characterized with long history of under-funding of education and incessant strikes by its education workforce.

Indeed, the dwindling quality of education witnessed in Nigeria in the last 30 years, can largely be traced to work conditions, which many scholars have affirmed contributed significantly to low morale and poor job satisfaction that is predominant among the teaching workforce.

Teachers in the secondary schools are the life-wire of the secondary school system. Whereas it is an undisputable statement that no education system may rise above the quality of its teachers (FRAN 2004), it is equally undisputable that not much can be achieved in terms of school goals attainment if the morale of teachers are low. This is true because even teachers with the highest qualifications still need to be motivated to achieve result.

Psychologists agree that the highest need of human being is that of achievement or self actualization which encompasses not only the ability to accomplish, but the need for actual achievement of something in life, and, the job remains the major source of satisfaction of this need (Fippo 1982). Scholars are also in agreement that the most important factor in teacher motivation is better pay, and good conditions of service Edem (1987:60) had noted that "the morale of teachers are likely to fall if there are noticeable disparities between their conditions of service and those of others". For teachers to be effective in their job, they must be assured of good pay packet, adequate provision for advancement, promotions and other benefits enjoyed by people in other professions.

\section{Statement of Problem}

In the last 20 years or more, the quality of secondary education has continued to deteriorate, largely because of the quality of instructional delivery. In some instances, the products of the system are found not able to spell three latter words, and correctly place their tenses. The popular view is that the poor learning outcome is associated with the quality of teachers in the system. Unfortunately, many people appear to be scarcely bothered about teachers' motivation and its related factors and the likely implications of these on teacher productivity.

With the massive investment in infrastructural development in education in Rivers State to address the long years of decay in the education sector, concrete steps need to be equally taken to address teacher related problems, especially in the area of teacher motivation. This will help ensure that the investment in infrastructure does not waste.

As a result, the researchers in this study are specifically bothered by the need to establish whether secondary school teachers are motivated on their job to achieve result, their specific motivation areas (if they are), and the possible implications of the observed motivational level on human resource management in secondary schools.

\section{Theoretical Framework}

This study is anchored on Abraham Maslow's needs hierarchy theory. The needs hierarchy theory as propounded by Abraham H. Maslow (1954) in his work "motivation and personality' has turned out to be the most widely referred and acclaimed theory in the study of human motivation even though it has been criticized by most scholars (Hoy \& Miskel, 1987). Abraham Maslow was a clinical psychologist and he categorized human needs into five categories from lowest to highest, arranged in their order to pre-potency. He sees man as a wanting being who is motivated by the needs he wants to satisfy. He believes that these needs are universal and that the lower levels of needs must be relatively satisfied before the higher needs are activated to begin to motivate behavior. Maslow points out that once a need is satisfied, it no longer dominates behavior and another need then arises to take its place.

The levels of Maslow's need hierarchy from lowest to highest include; 
1) Physiological or Basic Needs

These include needs to satisfy hunger, thirst, sex, shelter, and other bodily needs. Physiological needs are the most basic and their fulfillment is essential for survival.

2) Safety Needs

Safety needs include security and protection from physical and emotional harm. They are needs for freedom from threat, danger, or deprivation, and involve self preservation.

3) Belongingness and Love Needs

These include the desire for affection, belongingness, acceptance, and friendship. These are concerned with an individual's ability to exist in harmony with other people.

4) Esteem Needs

These include needs for self- respect, achievement, competence, autonomy self- confidence, status, recognition, attention, dignity and appreciation, when these needs are satisfied, a sense of adequacy results, but when they are not satisfied, it produces feelings of helplessness and inferiority.

5) Self-Actualization Needs

This means to become more and more what of one to become everything that one is capable of becoming.

Maslow views an individual's motivation in terms of a pre-determined order of needs each with its own rank.

\section{Methodology}

The research is a descriptive survey study. A sample of 500 teachers were drawn from 245 secondary school across the 23 local government areas of Rivers State. A 25-item questionnaire was designed, validated by relevant experts, tested for reliability (with an r-coefficient of 0.97) and administered to elicit information for the study. The administration of the instrument achieved 95\% response/return rate. Weighted mean and rank order were applied for descriptive analysis.

\section{Results and Discussions}

5.1 Level of Achievement of Abraham Maslow's Lower Order Needs by Secondary School Teachers

Table 1: Mean and rank Order (RO) of the Assessment of The Level of Achievement of Abraham Maslow's Lower Order Needs among Secondary School Teachers in Rivers State

\begin{tabular}{llll}
$\mathbf{S} / \mathbf{N}$ & Lower Order Needs Indicators & $\mathbf{X}$ & $\mathbf{R o}$ \\
\hline 1 & Satisfaction of hunger needs & 2.46 & $4^{\text {th }}$ \\
2 & Satisfaction of thirst needs & 2.80 & $1^{\text {st }}$ \\
3 & Satisfaction of shelter needs & 1.97 & $7^{\text {th }}$ \\
4 & Satisfaction of sex needs & 2.70 & $2^{\text {nd }}$ \\
5 & Security needs & 1,91 & $8^{\text {th }}$ \\
6 & Satisfactory association with others & 2.50 & $3^{\text {td }}$ \\
7 & Belonging to groups & 2.19 & $6^{\text {th }}$ \\
8 & Love, friendship and affection & 2.23 & $5^{\text {th }}$ \\
\hline
\end{tabular}

The first needs examined by the study is the level of achievement of Abraham Maslow's lower order needs by teachers in secondary schools, which was determined by teachers' responses to 8 lower order needs indication variables in the research questionnaire. The weighted mean and rank order of their responses as shown in table 1 reveal that teachers indication of their achievement of lower order needs is moderately reflected in the satisfaction of thirst needs which ranked first (with a mean score of 2.80), and satisfaction of sex need which ranked second with a mean score of 2.70). The result also reveals that association with others ranked third (with a mean score of 2.50) hunger need ranked $4^{\text {th }}$ with a mean score of 2.46. Love, friendship and affection ranked fifth with a mean score of 2.23). Belonging to group ranked sixth (with a mean score of 2.19); shelter needs ranked seventh (with a 
mean score of 1.97); while security needs ranked eight (with a mean score of 1.91).

The meaning of the weighted mean scores that fell below 2.50 on a four-point scale is that teachers express very minimal achievement in these areas. The result shows that the level of achievement of Abraham Maslow's lower order needs among secondary school teachers is very minimal. These indicators are the basis of motivation. Until these physiological needs are relatively satisfied by teachers, they may not be able to put in their best in school goal attainment. For example, as rightly observed by Abraham (2003), a teacher who does not have food in his house and probably did not sleep well the previous night while thinking of how to get money to buy food, will either not come to school, or where he comes, will not function effectively. These levels of needs for an employee should be satisfied with the salary. It is evident from the observed result that in Rivers State and indeed Nigeria, teachers constantly labour to satisfy this common need. It is not surprising then that a good number of them, in order to fulfill their desire go extra miles to impose illegal levies, and extort money from students and get involved in unimaginable acts to make ends meet, and in the process compromise quality of education. The present finding is in agreement with previous finding of Oparah (2005) that teachers in the secondary school system are not adequately motivated for the performance of their job.

Human needs and motivations are key elements in determining how individuals behave in an organizations. Individuals working in an organization are always concerned about fulfilling their needs in the course of doing their jobs. One reason why teachers take up teaching appointment is to fulfill their needs. Consequently, the extent to which they will achieve result in terms of school goal attainment is determined by their individual need fulfillment.

\subsection{Level of Achievement of Higher Order Needs among Secondary School Teachers in Rivers State}

Table 2: Mean and Rank Order of the Level of Achievement of Abraham Maslow's Higher Order Needs among Secondary School Teachers

\begin{tabular}{llll}
$\mathbf{S} / \mathbf{N}$ & Lower Order Needs Indicators & $\overline{\mathbf{X}}$ & $\mathbf{R O}$ \\
\hline 1 & Self respect & 2.44 & $1^{\text {st }}$ \\
2 & Status and recognition & 2.05 & $3^{\text {rd }}$ \\
3 & Dignity and appreciation & 1.98 & $5^{\text {th }}$ \\
4 & Self actualization & 1.86 & $6^{\text {th }}$ \\
5 & Self- expression & 2.36 & $2^{\text {nd }}$ \\
6 & Achievement of Potential self development. & 2.03 & $4^{\text {th }}$
\end{tabular}

In table 2 , six higher order need indicators were assessed to determine their level of achievement among secondary school teachers. The result reveals in descending order of rank and mean scores that achievement of self respect ranked $1^{\text {st }}$ (with a mean score of (2.23); self expression $2^{\text {nd }}$ (1.36); status and recognition $3 \mathrm{rcd}$ (2.05); achievement of potential self development $4^{\text {th }}(2.03)$; dignity and appreciation $5^{\text {th }}(1.98)$, and self actualization $6^{\text {th }}(1.86)$. The mean score of all the assessed indicators were below 2.50. This means that they are rarely achieved. It is therefore not surprising that the respondents had rated them low.

The clear result from this is that secondary school teachers are not admired and respected by members of the society. The result equally indicates that there is lack of confidence even among the teachers themselves because of poor achievement. It must be noted that growth towards self actualization requires the satisfaction of basic needs.

Fredrick Herzberg and his colleagues (Herzberg, Mausner, and Snyderman,) (1959), in their now famous study of motivation and job satisfaction found that the factors leading to positive job attitudes (ie motivators) do so because of their potential to satisfy the individual['s need for self actualization (Hoy \& Miskel, 2008). Their findings also revealed that the gratification of certain needs called motivators (ie, achievement, recognition, work itself, responsibility and advancement), increases satisfaction, but when the motivators are not gratified, only minimal dissatisfaction results. These observed factors as source of motivation and job satisfaction play significant role in teacher's job performance and productivity in the secondary school system and only attest to the poor quality of secondary education since the teachers are poorly motivated.

\subsection{Implication for Human Resource Management in the Secondary School System}

The result of this study as presented and discussed above has far reaching implications for human resource management in the secondary school system in particular and the education sector in general. Firstly, the observed 
low level of motivation among teachers frustrates commitment, which ultimately lowers productivity. Considering the fact that teachers' motivation is significantly determined by variables such as salary and conditions of work, it follows that majority of them might be forced to go to any length to meet their family and social responsibilities. It is either they engage in other activities outside their normal teaching job or they compromise quality, all for material gains. It is not surprising then that the system is fraught with high level of examination malpractice. The end result is that the quality of education at the secondary school level has been lowered.

The second dimension is that best brains are not attracted into the teaching profession, but would rather prefer occupations that pay well. When any occupation seizes to replenish itself, the profession is doomed. The third dimension is the massive attrition of teachers to highly paid private sector companies and establishments with better work conditions and remunerations. This, possibly explains the continued dearth of teachers in the secondary school system inspite of government perceived attempt to improve on the teaching and learning conditions of schools.

\section{Conclusions and Recommendations}

The study concludes that teachers motivation is a very significant factor in teacher productivity. The study reveals that the following factors are known to have affected teacher motivation: satisfaction of hunger needs; shelter needs; security needs; belongingness, love friendship and affection needs. It is equally true that secondary school teachers are not socially recognized and respected like people in other professions. This is reflected in the poor status accorded the profession by members of the society including the very students they teach.

The implications of the above on human resource management in the secondary school system is that teachers will definitely and invariably get themselves involved in fraudulent activities including examination malpractice, to make ends meet. Furthermore, the low level of motivation among teachers could be reflected in the lowering of standards and the poor quality education experienced at the secondary school level. Since teachers' motivation level is low, they will not be able to meaningfully carry out their teaching responsibility. This will inadvertently affect productivity and efficiency.

Arising from the findings of this study, the researchers hereby advance some recommendations towards the effective management of human resource and hence, performance of teachers in the secondary school system. Firstly, there is urgent need for governments to seriously address the remunerations of teachers and keep it at par with other professions. This will attract best brains into the system and eliminate situations where neophytes are attracted to teach.

Government must muster the will power to upgrade teaching /learning facilities in the secondary school system as is presently done at the primary school level in Rivers State. This is true because economic principles have shown that increase in salary alone does not guarantee solution to lack of money, but improvement on working environment and living conditions would go a long way to boost teachers morale and energies them to be more productive.

\section{References}

Abraham, Nath M. (2003). Educational administration in Nigeria. Port Harcourt: Pam unique pub. Coy Ltd.

Bateman. T.S., \& Snell, S.A (1999). Management- building competitive advantage. Boston: Irwin McGraw hill.

Edem, D.A. (1987). Introduction to Educational Administration in Nigeria. Ibadan: spectrum book Ltd.

Federal republic of Nigeria. (2004). National Policy on Education. Lagos: NERC.

Flippo, E. B. (1982). Personnel Management. Tokoyo: McGraw.

Heifder, Fritz (1958). The psychology of interpersonal Relations. New York: John Wiley. http://dx.doi.org/10.1037/10628-000

Hoy, W.K., \& Miskel, C.Y. (2008). Educational Administration: Theory Research and practice. New York McGraw- hill coy.inc.

McGregor, Douglas. (1960). The human side of enterprise. New York: McGraw hill book coy.

Oparah M.A (2005). Teacher preparedness for quality delivery of secondary education in Ikwerre specking Local Government Areas of rivers state unpublished M.Ed. Thesis. 